\title{
Front Matter: Volume 11211
}

, "Front Matter: Volume 11211," Proc. SPIE 11211, Photonics in Dermatology and Plastic Surgery 2020, 1121101 (27 February 2020); doi:

10.1117/12.2569472

SPIE. Event: SPIE BiOS, 2020, San Francisco, California, United States 


\title{
PROGRESS IN BIOMEDICAL OPTICS AND IMAGING

\section{Photonics in Dermatology and Plastic Surgery 2020}

\author{
Bernard Choi \\ Haishan Zeng \\ Editors
}

1-2 February 2020

San Francisco, California, United States

Sponsored by

SPIE

Cosponsored by

Johnson \& Johnson Consumer Inc. (United States)

Published by

SPIE 
The papers in this volume were part of the technical conference cited on the cover and title page. Papers were selected and subject to review by the editors and conference program committee. Some conference presentations may not be available for publication. Additional papers and presentation recordings may be available online in the SPIE Digital Library at SPIEDigitalLibrary.org.

The papers reflect the work and thoughts of the authors and are published herein as submitted. The publisher is not responsible for the validity of the information or for any outcomes resulting from reliance thereon.

Please use the following format to cite material from these proceedings:

Author(s), "Title of Paper," in Photonics in Dermatology and Plastic Surgery 2020, edited by Bernard Choi, Haishan Zeng, Proceedings of SPIE Vol. 11211 (SPIE, Bellingham, WA, 2019) Seven-digit Article CID Number.

ISSN: 1605-7422

ISSN: 2410-9045 (electronic)

ISBN: 9781510631854

ISBN: 9781510631861 (electronic)

Published by

SPIE

P.O. Box 10, Bellingham, Washington 98227-0010 USA

Telephone +1 3606763290 (Pacific Time) · Fax +1 3606471445

SPIE.org

Copyright (c) 2020, Society of Photo-Optical Instrumentation Engineers.

Copying of material in this book for internal or personal use, or for the internal or personal use of specific clients, beyond the fair use provisions granted by the U.S. Copyright Law is authorized by SPIE subject to payment of copying fees. The Transactional Reporting Service base fee for this volume is $\$ 21.00$ per article (or portion thereof), which should be paid directly to the Copyright Clearance Center (CCC), 222 Rosewood Drive, Danvers, MA 01923. Payment may also be made electronically through CCC Online at copyright.com. Other copying for republication, resale, advertising or promotion, or any form of systematic or multiple reproduction of any material in this book is prohibited except with permission in writing from the publisher. The CCC fee code is $1605-$ $7422 / 20 / \$ 21.00$.

Printed in the United States of America by Curran Associates, Inc., under license from SPIE.

Publication of record for individual papers is online in the SPIE Digital Library.

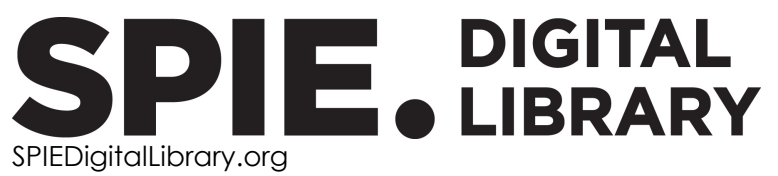

Paper Numbering: Proceedings of SPIE follow an e-First publication model. A unique citation identifier (CID) number is assigned to each article at the time of publication. Utilization of CIDs allows articles to be fully citable as soon as they are published online, and connects the same identifier to all online and print versions of the publication. SPIE uses a seven-digit CID article numbering system structured as follows:

- The first five digits correspond to the SPIE volume number.

- The last two digits indicate publication order within the volume using a Base 36 numbering system employing both numerals and letters. These two-number sets start with $00,01,02,03,04$, 05, 06, 07, 08, 09, 0A, OB ... 0Z, followed by 10-1Z, 20-2Z, etc. The CID Number appears on each page of the manuscript. 


\title{
Contents
}

\author{
$\checkmark \quad$ Authors \\ vii Conference Committee
}

SPATIAL FREQUENCY DOMAIN IMAGING

1121105 Experimental integration of a spatial frequency domain spectroscopy and pulse cam system for quantifying changes in skin optical properties and vasculature among individuals with obesity [11211-3]

1121106 Using Spatial Frequency Domain Imaging (SFDI) to quantify physiological changes of patients undergoing radiotherapy for breast cancer treatment [1 1211-4]

\section{SKIN CANCER}

1121108 Multimodal optical imaging for in vivo discrimination of equivocal melanocytic skin lesions [11211-6]

1121109 Visible light optical coherence microscopy for quantitative imaging of human skin in vivo [11211-7]

$112110 \mathrm{~A}$ Polarization sensitive optical coherence tomography for assessing skin roughness [1 1211-8]

\section{MACHINE LEARNING}

$11211 \mathrm{OB} \quad$ Automatic classification of melanocytic skin tumors based on hyperparameters optimized by cross-validation using support vector machines [1 121 1-9]

\section{THERAPEUTICS}

$112110 \mathrm{M}$ A novel method for direct measurement of optical fluence of focused laser energy in ex-vivo skin [11211-20]

\section{OPTICAL COHERENCE TOMOGRAPHY}

$112110 R \quad$ Depth-resolved investigation of multiple optical properties and wrinkle morphology in eyecorner area by multi-functional Jones matrix optical coherence tomography [11211-25] 
11211 OS Handheld line-field confocal optical coherence tomography for dermatology [11211-26]

\section{SKIN CHARACTERIZATION/BIOLOGICAL RESPONSE}

11211 OV Rapid handheld screening device to detect skin and soft tissue infections [11211-29]

$112110 X$ Characterization of tattoos in human skin using pulsed photothermal radiometry and diffuse reflectance spectroscopy [11211-31]

$112110 Z$ Hemodynamics in traumatic bruises assessed by diffuse reflectance spectroscopy and photothermal radiometry [11211-33]

1121110 Skimager for the objective erythema estimation in atopic dogs [11211-35]

\section{POSTER SESSION}

1121114 Video-mosaicking of human skin in vivo using handheld line-field confocal optical coherence tomography [11211-39]

1121116 Non-contact fast Mueller matrix measurement system for investigation of bio-tissues [11211-42] 


\section{Authors}

Numbers in the index correspond to the last two digits of the seven-digit citation identifier (CID) article numbering system used in Proceedings of SPIE. The first five digits reflect the volume number. Base 36 numbering is employed for the last two digits and indicates the order of articles within the volume. Numbers start with 00, 01, 02, 03, 04, 05, 06, 07, 08, 09, OA, OB...0Z, followed by 10-1Z, 20-2Z, etc.

Adelusi, Sean, 06

Al-Ghazi, Muthana, 06

Becker, Alexander, 16

Bhawalkar, Jayant, $0 \mathrm{M}$

Boonya-ananta, Tananant, 05

Cazalas, Maxime, OS, 14

Chen, Nanguang, 09

Chong, Shau Poh, 09

Cinotti, Elisa, OS

Cugmas, Blaž, 10

Darovi, Parima, 06

Daures, Anthony, 14

Davydova, Diana, 08

del Marmol, Véronique, OS

Dubois, Arnaud, OS, 14

Durkin, Anthony J., 06

Elagin, Vadim, 08

Erenburg, Irina, $0 \mathrm{M}$

Fricke, Dierk, 16

Ganvir, Devina, OV

Garanina, Oksana, 08

Glasmacher, Birgit, 16

Gokkan, Ozan, OB

Gubarkova, Ekaterina, 08

Gupta, Aayush, OV

Hibert, Matthew L., OM

Huang, Lin, $\mathrm{OA}$

Jütte, Lennart, 16

Katkam, Rajender, OM

King, John, OV

Klemenova, Irina, 08

Ko, Zhen Yu Gordon, 09

Kobayashi, Masaki, OR

Kuo, Jeffrey, 06

Lee, Tim K., OA

Leproux, Anaïs, 06

Levecq, Olivier, OS, 14

Levine, Lewis, $0 M$

$\mathrm{Li}$, En, OR

Liu, Qihao, OA

Lovie, Daniel C., OA

Lukač, Matjaž, OX

Maity, Akash Kumar, 05

Majaron, Boris, OX, OZ

Makita, Shuichi, OR

Maloufi, Sina, OA

Malvehy, Josep, os

Marin, Ana, $\mathrm{OZ}$

Miyazawa, Arata, OR
Ogien, Jonas, OS, 14

Olivrī, Alla, 10

Olivry, Thierry, 10

Orlinskaya, Natalia, 08

Perrot, Jean-Luc, OS

Ponticorvo, Adrien, 06

Radhakrishnan, Geethanjali, OV

Ramella-Roman, Jessica C., 05

Ramsinghani, Nilam, 06

Rodriguez, Andres J., 05

Roth, Bernhard, 16

Rowland, Rebecca, 06

Rubegni, Pietro, OS

Saager, Rolf B., 05

Sakai, Shingo, OR

Sayo, Tetsuya, OR

Shaughnessy, Patrick, OM

Shlivko, Irena, 08

Spīgulis, Jānis, 10

Suppa, Mariano, OS

Takahashi, Yoshito, OR

Tang, Shuo, OA

Tchvialeva, Lioudmila, OA

To, Tania, OM

Tozburun, Serhat, OB

Veeraraghavan, Ashok, 05

Verdel, Nina, OX, OZ

Wei, Randy, 06

Wollweber, Merve, 16

Yamazaki, Kohei, OR

Yasuno, Yoshiaki, OR

Zagaynova, Elena, 08

Zhou, Xin, OA 
Proc. of SPIE Vol. $112111121101-6$

Downloaded From: https://www.spiedigitallibrary.org/conference-proceedings-of-spie on 26 Apr 2023 Terms of Use: https://www.spiedigitallibrary.org/terms-of-use 


\title{
Conference Committee
}

\author{
Symposium Chairs
}

Jennifer Barton, The University of Arizona (United States)

Wolfgang Drexler, Medizinische Universität Wien (Austria)

Program Track Chairs

Brian Jet-Fei Wang, Beckman Laser Institute and Medical Clinic,

University of California, Irvine (United States)

Eva Sevick, The University of Texas Health Science Center at Houston (United States)

\section{Conference Chairs}

Bernard Choi, Beckman Laser Institute and Medical Clinic, University of California, Irvine (United States)

Haishan Zeng, BC Cancer Research Center (Canada)

\section{Conference Program Committee}

Anthony J. Durkin, Beckman Laser Institute and Medical Clinic, University of California, Irvine (United States)

Conor L. Evans, Wellman Center for Photomedicine (United States)

Manu Jain, Memorial Sloan-Kettering Cancer Center (United States)

Kristen M. Kelly, University of California, Irvine School of Medicine (United States)

Boris Majaron, Jožef Stefan Institute (Slovenia)

Milind Rajadhyaksha, Memorial Sloan-Kettering Cancer Center (United States)

Jessica C. Ramella-Roman, Florida International University (United States)

Lise Lyngsnes Randeberg, Norwegian University of Science and Technology (Norway)

Rolf B. Saager, Beckman Laser Institute and Medical Clinic (United States)

InSeok Seo, Johnson \& Johnson Consumer Products (United States)

Eric R. Tkaczyk, Vanderbilt University Medical Center (United States)

Hequn Wang, Johnson \& Johnson Consumer Products (United States)

Ruikang K. Wang, University of Washington (United States) 


\section{Session Chairs}

$1 \quad$ Spatial Frequency Domain Imaging

Jessica C. Ramella-Roman, Florida International University

(United States)

2 Skin Cancer

Manu Jain, Memorial Sloan-Kettering Cancer Center (United States)

Inga Saknite, Vanderbilt University Medical Center (United States)

3 Machine Learning

Boris Majaron, Jožef Stefan Institute (Slovenia)

4 Confocal and Multiphoton Microscopy I

Milind Rajadhyaksha, Memorial Sloan-Kettering Cancer Center (United States)

5 Kollias Memorial Lecture: Current Problems in Dermatology

Haishan Zeng, BC Cancer Research Center (Canada)

Bernard Choi, Beckman Laser Institute and Medical Clinic, University of California, Irvine (United States)

6 Therapeutics

Bernard Choi, Beckman Laser Institute and Medical Clinic, University of California, Irvine (United States)

7 Confocal and Multiphoton Microscopy II

Conor L. Evans, Wellman Center for Photomedicine (United States)

8 Optical Coherence Tomography

Ruikang K. Wang, University of Washington (United States)

9 Skin Characterization/Biological Response

Rolf B. Saager, Linköping University (Sweden)

InSeok Seo, Johnson \& Johnson Consumer Products (United States)

Haishan Zeng, BC Cancer Research Center (Canada) 